\section{Outbreak prevalence of Newcastle disease in Erbil and surrounding areas (Iraq)}

Zahir Abdullateef J. Babaca

Department of Nursing, Bardarash Technical Institute, Dohuk Polytechnic University, Iraq

Abstract

The researcher has selected 17 farms in and around Erbil City (Iraq) with a history of Newcastle Disease (ND) outbreaks for the investigation during late spring, summer and winter of 2008, a time of the year when the outbreaks in Erbil start to occur. The strain of birds (all vaccinated with Lasota strain) including age, clinical diagnostic lesions, flock strength and mortality rate, were recorded. The study found that fowls with ages of (1-8 weeks) were susceptible to ND and that the mortality rate was $(8.1 \%)$ in chicks broilers.

\section{Introduction}

Newcastle Disease (ND), or as it is also named avian distemper, avian pneumoencephalitis, or Korean fowl plague, $, 1,2$ is a contagious and fatal strain which is carried by numerous wild and domestic bird species. ${ }^{3}$ Newcastle disease virus is a paramyxovirus that is contagious and fetal to avian fauna. It is probably one of the most infectious diseases of poultry worldwide with death rates of 100 percent in unvaccinated flocks. 1,4,5 Newcastle Disease Virus (NDV) was first isolated in 1926 and for 30 years remained the only known avian paramyxovirus. The history of Newcastle disease is marked by at least three panzootics in domestic birds. The second and third panzootic was in the middle East in the late 1960s/Middle 1980s. ${ }^{4}$ Large numbers of birds die without showing any clinical signs, and the virus may even cause mortality in vaccinated flocks as well. 6,7

The clinical signs are very variable depending on the strain of virus and magnitude of vaccination. ${ }^{8}$ Acute and sub-acute strains
Correspondence: Zahir Abdullateef Jameel Babaca, Department of Nursing, Bardarash Technical Institute, Dohuk Polytechnic University, 61 zakho Road, 1006 Mazi Qr Duhok, Kurdistan-Iraq

Tel.: +96.475.041.28389.

E-mail: techmag2011@yahoo.com

Key words: outbreak, Newcastle disease, Erbil City.

Conflict of interests: the author declares no potential conflict of interests.

Received for publication: 22 March 2014.

Revision received: 29 May 2014.

Accepted for publication: 27 May 2014.

This work is licensed under a Creative Commons Attribution NonCommercial 3.0 License (CC BYNC 3.0).

(C) Copyright Z.A. J. Babaca., 2015

Licensee PAGEPress srl, Italy

Veterinary Science Development 2015; 5:2015 doi:10.4081/vsd.2015.2015

Table 1. Vaccination program, mortality number and mortality rate in the $\mathbf{1 2}$ districts.

\begin{tabular}{|c|c|c|c|c|}
\hline District & Chick broilers & Vaccination programs & Mortality numbers & Mortality rate (\%) \\
\hline Khabat & 15,000 & $\begin{array}{l}\text { ND: day } 1,7,9,19 \\
\text { IDB: day } 17\end{array}$ & 1024 & 6.8 \\
\hline Gardarash & 15,000 & $\begin{array}{l}\text { ND: day } 1,5,21 \\
\text { IDB: day } 19\end{array}$ & 990 & 6.6 \\
\hline Quocha-bilbas & 10,000 & $\begin{array}{l}\text { ND: day } 1,10 \\
\text { IDB: day } 14\end{array}$ & 2100 & 21 \\
\hline Banaman & 7500 & $\begin{array}{l}\text { ND: day } 8,16,24,32 \\
\text { IDB: day } 13\end{array}$ & 80 & 1.06 \\
\hline Kawreen & 7000 & $\begin{array}{l}\text { ND: day } 7,21 \\
\text { IDB: day } 11,17\end{array}$ & 1395 & 19.9 \\
\hline Shawess & 5000 & $\begin{array}{l}\text { ND: day } 1,14,30 \\
\text { IDB: day } 9\end{array}$ & 110 & 2.2 \\
\hline Banslawa & 9000 & ND: day $10,20,30$ & 130 & 1.4 \\
\hline Qarajnakha & 6600 & $\begin{array}{l}\text { ND: day } 1,15,24 \\
\text { IDB: day } 7,13\end{array}$ & 89 & 1.3 \\
\hline Ankawa & 20,000 & $\begin{array}{l}\text { ND: day 9,18 } \\
\text { IDB: day } 12\end{array}$ & 350 & 1.75 \\
\hline Koya & 5000 & $\begin{array}{l}\text { ND: day } 11,21 \\
\text { IDB: day } 9,19\end{array}$ & 110 & 2.2 \\
\hline Koya & 8000 & $\begin{array}{l}\text { ND: day } 11,21 \\
\text { IDB: day } 9,19\end{array}$ & 550 & 6.8 \\
\hline Koya & 12000 & $\begin{array}{l}\text { ND: day } 9,21,36 \\
\text { IDB: day } 12,18\end{array}$ & 1175 & 9.8 \\
\hline Koya & 5000 & $\begin{array}{l}\text { ND: day } 11,21 \\
\text { IDB: day } 9,19\end{array}$ & 1455 & 29.1 \\
\hline Shaqlawa & 10,000 & $\begin{array}{l}\text { ND: day } 1,12,21,40 \\
\text { IDB: day } 12\end{array}$ & 300 & 3 \\
\hline Shaqlawa & 7000 & $\begin{array}{l}\text { ND: day } 12,20 \\
\text { IDB: day } 12\end{array}$ & 1070 & 15.2 \\
\hline Harer & 27,000 & $\begin{array}{l}\text { ND: day } 1,14,30 \\
\text { IDB: day } 12,20\end{array}$ & 220 & 0.8 \\
\hline Harer & 27,000 & $\begin{array}{l}\text { ND: day } 1,14,30 \\
\text { IDB: day } 12,20\end{array}$ & 2655 & 9.8 \\
\hline
\end{tabular}


cause respiratory signs (such as sneezing, gasping for air, nasal discharge and coughing), drop in egg production, egg-shell softening, greenish loose feces, and some torticollis or other nervous signs (like depression, drooping wings, twisting of head and neck). Per-acute strains cause sudden death.6,9,10 Over 250 species of birds have been reported susceptible to natural or experimental NDV infection and it seems probable that many are fully susceptible. ${ }^{9}$ Economically, the disease is seen significant and poses concerns throughout the world because it causes continuous heavy economic loss over seas. ${ }^{9}$

\section{Materials and Methods}

Seventeen farms were randomly selected during late spring-summer and winter of 2008 , considering the high-mortality rate history, besides different altitudes and locations if compared with neighboring governorates or countries. These 17 farms were distributed on 12 different districts within Erbil governorate including Khabat, Gardarash, Quocha-bilbas,
Banaman, Kawreen, Shawess, Banslawa, Qarajnakha, Ankawa, koya, Shaqlawa and Harer. About 10-15 chick broilers have been examined from each different districts by visual examination to look for the diagnostic lesions of the disease.

\section{Results and Discussion}

The farm districts, number of dead chicks, vaccination programs, and mortality rates are presented in Table 1. It shows that there is a high variation in mortality rate due to ND and the highest mortality rate was in Koya district with $29.1 \%$, while the lowest rate $(0.8 \%)$ was recorded in Harer district. This variation may be attributed to the geographic distribution and use of ND vaccines in commercial poultry which makes the assessment of ND virus somewhat difficult. So, due to the fact that vaccinated birds may be infected with ND without showing severe clinical signs, infected carriers are not easily identifiable. This agreement coincides with other authors' findings. 1,3

Data presented in Table 1 also shows how

Table 2. The clinical diagnostic lesions of Newcastle disease with the percentages of the numbers of chick broilers were examined in different districts by a visual examination.

\begin{tabular}{lcc} 
Clinical diagnostic lesions & Numbers of chick broilers & $\%$ \\
Petechial hemorrhage in mucosa of Proventriculus & 12 & 80 \\
Hemorrhage in intestinal tract & 10 & 66.6 \\
\hline Inflammation of trachea + air sacs & 7 & 46.6 \\
Hemorrhage in spleen & 5 & 33.3 \\
\hline Petechial hemorrhage of heart & 3 & 20 \\
\hline
\end{tabular}

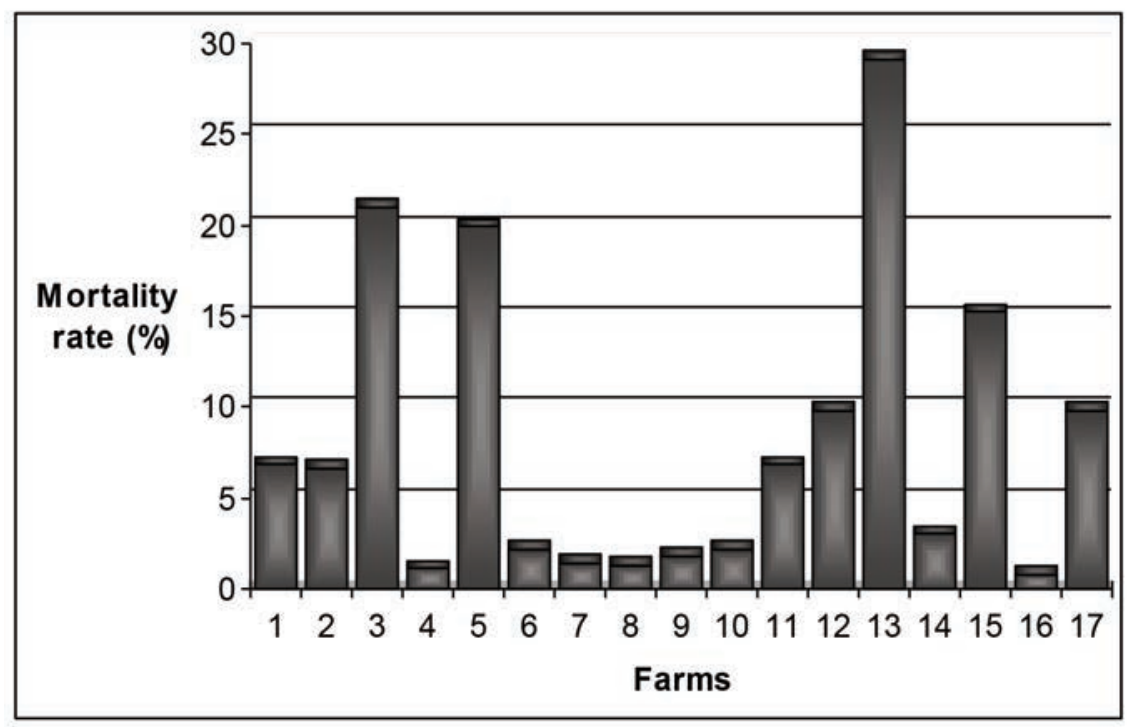

Figure 1. The mortality rate of chick broilers according to the total numbers.
ND outbreaks are highly spread in many districts in and around Erbil city. As a result, ND virus becomes endemic in Erbil (Iraq) and many parts of the world including countries in Asia, the Middle East, Africa, and Central and South America. This result was confirmed by observations of several authors, $1,5,11$ despite the high speed of ND spread and different routes of transmission between the farms as the Figure 1 makes it clear.

The clinical diagnostic lesions of Newcastle disease with the percentages of the numbers of chick broilers were examined in different districts by visual examination during postmortem (Table 2). The Table shows that Petechial hemorrhage in mucosa of Proventriculus was the highest rate (80\%), with much more observed during postmortem. Hemorrhage in the intestinal tract came after that with (66.6\%). Meanwhile the Petechial hemorrhage of heart was the lowest rate with only (20\%) that was observed in birds infected with Newcastle disease. These results confirm the concept of other workers arguing that these variations were dependent on the strain of virus and its tissue tropism.1,2,4,10 Furthermore, the immunity status, age, and conditions under which they are reared may also greatly affect the development of disease signs.

\section{References}

1. Canadian Food Inspection Agency. Exotic Newcastle disease. Available from: http://www.inspection.gc.ca/animals/terrestrial-animals/ diseases /reportable /nd/hazard-specific-plan/ eng /139267012 9624/1392670192661

2. Herenda DC, Franco DA. Poultry and meat hygiene. Ames: Iowa State University Press; 1996. pp 239-251.

3. Pfitzer S, Verwoerd DJ, Gerdes GH, et al. Newcastle disease and avian influenza A virus in wild water fowl in South Africa. Avian Dis 2000;44:655-60.

4. Jordan F, Pattison M, Alexander D, Faragher T. Poultry diseases. 5th Ed. Philadelphia: WB Saunders Publishers; 2003. pp 259-268.

5. Spradbrow PB. Newcastle disease in village chicken. Poultry Sci Rev 1993-94;5:5796.

6. Meteyer CU, Docherty DE, Glasor LC, et al. Diagnostic findings in the 1992 epornitic of neurotropic velogenic Newcastle disease in double-crest cormorants from the upper Midwestern United States. Avian Dis 1997;44:171-80.

7. Pazhanivel N, Balsubramaniam GA, George VT, Mohan B. Study of natural outbreak of Newcastle disease in and around 
Namakkal. Indian Vet J 2002;79:293-4.

8. Al-Garib S0, Gielkens ALJ, Gruys E, Koch G. Review of Newcastle disease virus with particular reference to immunity and vaccination. Worlds Poultry Sci J 2003;59:185200.
9. Curtis P. A handbook of poultry and game bird diseases. 4th Ed. Oxford: British Library Catalogue; 1996. pp 61-62.

10. Randall CJ. Diseases and disorders of the domestic fowl and turkey. 2nd Ed. London: Mosby International Limited; 1998. pp 59-
60.

11. Gueye EF. The role of faimily poultry in poverty alleviation, food security and the promotion of gender equity in rural Africa. 